\title{
Enhancing data collection methods with qualitative projective techniques in the exploration of a university's brand identity and brand image
}

Dr Louise Spry

Nottingham Business School

Nottingham Trent University

Burton Street

Nottingham, UK. NG1 4BU

Email: louise.spry1@ntu.ac.uk

Dr Christopher Pich

Nottingham Business School

Nottingham Trent University

Burton Street

Nottingham, UK. NG1 4BU

Email: Christopher.pich@ntu.ac.uk

\section{Abstract}

This paper focuses on assessing the capabilities of projective techniques, in gaining a deeper insight into complex university corporate brands. In particular we will explore identities and how these might align with brand images in different departments and faculties. There are explicit calls for further research on projective techniques in new contexts in particular, and where and when they are most useful during data collection. Responding to this gap in the literature, this study adopts a two-staged approach to the research design utilising qualitative projective techniques as a supplement to more traditional methods of data collection. This paper provides an updated matrix on how qualitative projective techniques can be better utilised during the planning, research and analysis stages of research in different contexts. This can be employed to assist inexperienced and experienced individuals with projective techniques during the planning, research and analysis stages of research into corporate brands.

Key words Qualitative projective techniques, corporate brands, brand identity, brand image 


\section{Introduction}

Branding is increasingly being utilised to help provide universities with a competitive edge and attract prospective students (Stephenson, Heckert \& Yerger, 2015). In this respect universities and colleges are turning to branding as a means of differentiating their offerings (Jevons, 2006) as in the UK education sector where competition has increased (Pinar, Trap, Girard, \& Boyt, 2010), and where public universities are seeking to rely less on state funding (Furey et al, 2014; Chapleo, 2015). More specifically, a corporate brand can alleviate universities from a complex set of multi-faceted features (Hemsley-Brown \& Goonawardana, 2007) which include among others, accreditation, tuition fees, positions in league tables and status in the global marketplace, and reinforce an institution's unique selling point to multiple stakeholders, such as students, academics and funders (Whisman, 2009; Chapleo, 2010). However, communicating a consistent university brand to multiple stakeholders is problematic (Chapleo, 2011), not least because studies suggest that stakeholders can lack an emotional connection to a university (Chapleo, 2011; Clayton, 2012). Thus, it is unclear whether universities have developed authentic, convincing brand identities and in particular, how these might strengthen brand images in different departments and faculties of a university (He \& Balmer 2007; Steiner, Sundström, \& Sammalisto, 2013). It is these multiple identities and values held by staff and students that we need to capture and understand as this may provide uniqueness to a university (Jevons, 2006).

As a way of understanding how universities manage their corporate brands, this paper provides insight into universities across international contexts and their brand identity and image. This also allowed us to utilise different categories of qualitative projective techniques within two different Higher Education Institution (HEI) settings, adopting both qualitative and qualitative paradigms. Qualitative projective techniques are a sequence of methods that can help respondents express themselves in a way that is more emotion-driven and, rather than being difficult to articulate verbally, taps into the sub-conscious (Kay, 2001; Donoghue, 2002). Pich et al, (2018) call for further research on projective techniques in new contexts and particularly those that consider elements of a corporate brand. Further, literature that discusses qualitative projective techniques is sparse in particular, where and when they are most useful during data collection. Initially this paper will consider qualitative projective techniques and how their utilisation may be useful in drawing out more in-depth interpretations of the corporate brand. This is followed by a discussion on the concepts of corporate brand identity and image and the importance of their alignment in managing a corporate brand. The research design explains the more traditional approaches adopted for the research, in two key stages, together with a justification for different qualitative projective techniques applied as a supplement to these. Key findings highlighted are those that emerged from these supplementary add-ons, followed by a more detailed discussion on the impact the qualitative projective techniques had on the depth of these findings, and an adapted model as a result. Following the findings, the conclusion discusses new knowledge that has emerged together with areas for further research and limitations of the study.

\section{Qualitative Projective Techniques}

Projective techniques can be defined as a set of qualitative activities 'considered very useful in marketing practice...involve the use of stimulus that allow participants to project their subjective or deep-seated beliefs onto other people or objects' (Hofstede et al, 2007:301). Similarly, projective techniques have been conceptualised as a series of devices that allow respondents to articulate subconscious, repressed or often withheld feelings, opinions and perceptions by projecting these onto another character (Boddy 2005; Denzin and Lincoln 2017; Gordon and Langmaid 2008; Gronhoj and Gram 2020). In addition, projective techniques can provide access to the private conscious and unconscious inner-world of the respondent (Boddy 2004; Vince and Broussine 1996) which, Kay (2001) 
maintains can help respondents express themselves in a way that is more emotion-driven rather than remaining sub-conscious or difficult to articulate verbally (Donoghue, 2000). Projective techniques can even be used in interviews, within focus groups or as an independent method of inquiry (Bond and Ramsey 2010; Pettigrew 2008), with the aim to elicit rich perceptions, deep-seated attitudes and indepth feelings (De Carlo et al, 2009), which otherwise may remain hidden or repressed (Boddy 2005; Broeckelmann 2010; Mulvey and Kavalam 2010; Pettigrew 2008). Further, projective techniques can delve beneath the surface of explicitly stated attitudes, associations and perceptions (Bond and Ramsey 2010; Day 1989; Denzin and Lincoln 2017; Gordon 1999; Gordon and Langmaid 2008).

The use of projective techniques are not new data collection activities (Boddy 2005; Pich et al, 2015). Since the 1940s, academics and practitioners in marketing have 'borrowed' projective techniques from the field of psychology and apply the techniques as a series of pragmatic tools, which allow respondents to express their deep-seated attitudes, behaviours, feelings and personal perspectives (Boddy 2005; Denzin and Lincoln 2017; Escribanoa et al, 2020; Gordon 1999; Gordon and Langmaid 2008; Janetius et al, 2019). Indeed, projective techniques have been used in a number of different fields not least many years of psychological studies that have informed marketing of products and services and in particular brand images to enlighten media campaigns and advertising strategies (Day, 1989; Escribanoa et al, 2020; Janetius et al, 2019; Kay, 2001; Pich et al, 2018; Steinmann, 2009). Despite their more psychological origins projective techniques are considered useful in marketing practice (Farook, 2013) particularly market research (Boddy, 2005). Further, projective techniques can be used to 'tease out evidence about how people interpret and react to their organisation and work worlds' (Fisher 2010: 157) which Chandler \& Owen (2002: 100) describe as 'a "way in" to the invisible layers of the mind'. More specifically, Doherty \& Nelson (2010: 400) claim that projective techniques can be used to access consumers' 'unspoken values'. Therefore, projective techniques have the potential to capture more informative results than standalone focus groups or interviews due to their ability to enhance rapport, and reveal deeper insight by exploring feelings, attitudes, associations and perceptions (Boddy, 2005; Bond \& Ramsey, 2010; Hofstede et al, 2007). Further, projective techniques can be divided into six different categories (outlined in table 1 ).

\section{Table $1 \quad$ Projective techniques}

\begin{tabular}{|l|l|}
\hline Categories & Methods \\
\hline Association & $\begin{array}{l}\text { Connecting the research object with images, } \\
\text { words or thoughts }\end{array}$ \\
\hline Completion & Finishing stories, sentences or drawings \\
\hline Construction & $\begin{array}{l}\text { Compose a story, mould a sculpture, paint a } \\
\text { picture }\end{array}$ \\
\hline Choice ordering & Rank product benefits or groups of pictures \\
\hline Expressive & Role-playing, drawing, drama or dance \\
\hline Metaphors & Person, animal, cars \\
\hline
\end{tabular}

Source: Davies, 2004; Escribanoa et al, 2020; Hofstede, 2007; Janetius et al, 2019; Porr et al, 2011; Farook, 2013; Pich et al, 2015; Pich et al, 2018 ; Soley and Smith 2008 
There are similarities between the methods within categories for example, word associations could easily resemble sentence completion if one were to ask 'when I think of holidays....' (Hofstede, 2007; Farook, 2013). Similarly, Will et al, (1996) question the capabilities of the different techniques for example, is word association projecting respondents' own feelings onto a research object? A group of techniques that appear to be distinctly more projective are metaphors (Davies et al, 2004; Farook, 2013; Hofstede, 2007; Oswick \& Montgomery 1999) where respondents associate the research object to phenomena in an entirely different sphere. Davies et al, (2004: 130) claim the idea of projecting 'the organisation as person metaphor' is useful in identifying how different stakeholders view an organisation. For example, Oswick \& Montgomery (1999) asked respondents which animals or car parts they associated with their organisation.

Nevertheless, a number of researchers argue that qualitative projective techniques have limitations (Pettigrew 2008). For example, researchers should be mindful that projective techniques may reveal more of the inner world of the researcher rather than the perceptions and associations of the participant (Bell 1948; Boddy 2005; Ramsey et al, 2006). Therefore, researchers should continuously reflect on whether the appropriate projective technique has been used, reassess the instructions communicated to respondents to ensure they are clearly understood and ensure probing is practiced by the researcher throughout the activity. In addition, the perceived lack of reliability and validity of projective techniques have been raised as a limitation and the ambiguous nature of some of the expressions generated from the activities can impact on the researchers ability to draw meaningful conclusions from the methods (Pettigrew 2008). Projective techniques can also be time consuming, put pressure on the respondents unfamiliar with these activities and this may result in the variety of responses to be limited (Langford and McDonagh 2003; Pich et al, 2015). Despite the limitations, qualitative projective techniques have a series of benefits. For example, there is often 'no pre-work required from respondents, relatively uncomplicated, useful warm up exercise to help participants to relax and to get them involved' (Langford and McDonagh 2003:180) and allows respondents to express themselves 'in fuller, more subtle ways than they could in direct questioning' (Boddy 2005:247). Thus, projective techniques can be rewarding for researchers particularly as the activities are often lighthearted (Gordon and Langmaid 2008) and stimuli can be ambiguous (Broeckelmann 2010; Mulvey \& Kavalam 2010; Ramsey et al, 2006). This approach can therefore put respondents at ease as is it a nonintrusive approach and encourages more open discussion (Barbour, 2007; Donoghue, 2000), helps overcome embarrassment, fear or anxiety when respondents are asked to explain their thoughts and attitudes (Pettigrew \& Charters, 2008) or even a fear of being judged (Doherty \& Nelson, 2010). Moving away from the more mainstream approaches to methods deemed authentic and creative takes away from 'research tiredness' (Farook, 2013: 302) and can make data collection more interesting and even 'fun and engaging' both for interviewees and interviewers (Doherty \& Nelson, 2010). Projective techniques are less demanding verbally and can help overcome emotional, language and cultural barriers (Boddy, 2004; Porr et al, 2011).

Projective techniques can also be challenging. For example, researchers need to ensure they recognise the benefits, limitations and different categories of projective techniques and understand how to utilise and facilitate the qualitative activities otherwise this could limit their elicitation capabilities (Bell 1948; Boddy 2005; Ramsey et al, 2006). Therefore, researchers should adopt a rigorous approach to the application, usage and analysis of projective techniques and this systematic process can ameliorate disadvantages and increase the chances of capturing deep insight. For example, the practice of crosschecking, laddering or probing which involves respondents elaborating on their expressions can reveal additional insight; this in turn can strengthen validity with the analytical process (Boddy 2005; Pich et al, 2015). However, there are limited studies, which discuss the systematic process of utilising projective techniques, their capabilities and their use as supplements or add-ons. 
A number of scholars highlight the usefulness of projective techniques in capturing data for branding research (Donoghue, 2000) such as brand image (De Carlo et al, 2009; Hofstede, 2007; ; Moutinho et al, 2007; Tantiseneepong et al, 2012), brand reputation (Pich et al, 2018), brand personality (Prayag 2007) and brand experiences (Jiménez-Barreto et al, 2020). However, existing studies tend to focus on using projective techniques to investigate brands from an external customer/consumer perspective. Further, existing research seems to have neglected the usefulness of these techniques with employees inside organisations. Indeed, many typologies of brands such as product, service, political, celebrity and destination brands have been studied however research on corporate brands appears under-explored, particularly in the context of HEls. Are projective techniques appropriate to investigate $\mathrm{HEl}$ corporate brands which can be multi-layered, multi-faceted and involve multiple stakeholders inside, and outside the organisation? Before we attempt to explore this issue; we must define and identify key components of corporate brands.

\section{Corporate brands and projective techniques?}

Abratt and Kleyn (2012: 1053) maintain a corporate brand is 'the interface between the organisation's stakeholders and its identity'. Thus a strong corporate brand can help recruit leading academics and attract those students in underrepresented groups (Chapleo, 2010; Croxford \& Raffe, 2015; Pinar et al, 2011; Stephenson et al, 2015). A key task required in managing corporate brands therefore is to understand how elements such as brand identity and image are developed and managed at the corporate and sub-brand levels. Brand identity refers to how the organisation is perceived internally (He \& Balmer, 2007) while brand image concerns the organisation and how it is viewed externally, particularly in terms of distinctive attributes (Abratt \& Kleyn, 2012). If organisations have a strong identity it can help them to 'align with the marketplace, attract investment, motivate employees and serve as a means to differentiate their products and services' (Melewar \& Karaosmanoglu, 2006: 846) with features that are unique (Nandan, 2005). However, Waeraas \& Solbakk (2009) maintain that expressing a single identity for a university may be far too fragmented and complex while Jevons (2006) cites the University of Cambridge where the identity of their colleges is much more distinct than the entire University. Hemsley-Brown \& Gonnawardana (2007) refer both to the heritage of universities, and of their departments, and the fact that in the past universities have played a much less visible role in branding which has allowed different departments to develop strong brand identities of their own. Thus, brand identity concerns the more fundamental attributes, or values, of an organisation and the way an organisation goes about its everyday business. It is therefore important for employees to understand exactly what the identity is and what it actually stands for (Roper \& Fill, 2012). Uggla (2006: 786) points to the 'fundamental core values' that are inherent to an organisation which Harris and de Chernatony (2001) maintain need to align with those of employees, as the way in which they behave will either reinforce or weaken the brand's values.

De Chernatony \& Cottam (2006: 622) claim that companies whose culture and values are congruent with employees will have a much stronger brand that will genuinely be "lived" by employees. Indeed, if this congruence occurs culture may be the very source of a competitive advantage (Hatch \& Schultz, 2003). Balmer \& Gray (2003: 980) make the general claim that 'corporate brand values should be clearly articulated, concise, well defined and distinct'. Therefore, shared values will only occur if the consumer appreciates and understands what the brand message is trying to say (Nandan, 2005). Thus, values and behaviours of employees should align with brand values desired, as employees are central to the brand building process, and the way in which they behave will either reinforce or weaken the brand's values. It would therefore appear imperative to investigate these values in great depth utilising an appropriate approach. 
Examining HEls more specifically, other commentators suggest that the more a university's values fit with those of students, the less likely they are to drop out (Jevons, 2006; Balmer \& Liao, 2007). These 'desirable end states' (Lages \& Fernandes, 2005: 1563) can be further classified into object and individual values (Rokeach, 1973). It is the individual or 'personal values' (Lages and Fernandes, 2005: 1564) that are significant in the literature and described as those 'that underlie important goals of students ....' (Gutman \& Miaoulis, 2003:106) which 'deal with the end states of our existence ....' (Durvasula et al, 2011: 33). The importance of relationship building concerning values is mentioned by several authors (Durvasula et al, 2011; Timmor \& Rymon, 2005) as it is satisfying the students' values which may lead to 'a notable impact on the development and furtherance of their relationship with the university' (Durvasula et al, 2011:34). For example, students' involvement with a corporate brand and the degree award is exceptionally important and highly emotional and therefore provides a student with an important sense of identity (Balmer \& Liao, 2007). The idea of brand values in a university is an unexplored area in the literature, and taking into consideration the diversity of universities, it may be a way of developing an identity that is truly distinct (Waerass, 2008).

In contrast to brand identity, stakeholders create the concept of brand image in their minds (Aaker \& Joachimsthaler 2002). Brand image is defined 'as the consumer's mental picture of the offering' (Cretu \& Brodie 2007:231), and characterised as the current, most recent associations consumers ascribe to brands (Nandan, 2005). Organisations do not necessarily create brand image rather, it represents how consumers understand and manifest perceptions, attitudes and feelings based on short-term interpretations of a brand (Argenti \& Druckenmiller, 2004; de Chernatony, 1999; Perez, 2015). Further, when stakeholders experience the corporate brand they develop related brand images (Abratt \& Kleyn, 2012) that can change over time and new images compared with earlier images (Rindell \& Strandvik, 2010). Gutman \& Miaoulis, (2003:106) describe this as 'a network of linkages between all the cognitive and emotional elements' evoked by the name of an organisation. A number of authors discuss the importance of a university's brand image as it influences a student's loyalty, and their satisfaction with a university (Alves \& Raposo, 2010; Schlesinger et al, 2016). Further, Gutman \& Miaoulis (2003) maintain that a positive brand image can be a key driver in influencing a student to attend a particular university and it is therefore important to understand the students' associations with the university's brand in relation to its image.

The concepts of brand identity and brand image are often used interchangeably as there is much misunderstanding of these two concepts and ideally, both elements should be aligned so that staff become 'walking representatives of the brand' (Kotler, Keller, Brady Goodman \& Hansen, 2009: 452). Hatch \& Schultz (2001) stress the importance of reducing the gaps between identity and image and achieving coherence across stakeholders as it is the corporate image that can be the most effective form of differentiation (Davies \& Chun, 2002). However, research has failed to explore how universities develop and manage their corporate brands to ensure consistency between brand identities and images.

To date there are no specific studies that have explored different identities which may have evolved in specialist university departments. Indeed some university faculties do not see themselves as part of the university's overall identity (Steiner, Sundström \& Solbakk, 2008) particularly those operating in niche markets. These different 'sub-brands' (Chapleo, 2007) consist of multiple stakeholders with competing priorities, yet the pressure to differentiate is key to gaining a competitive advantage in an increasingly saturated market (Anctil, 2008; Chapleo, 2010; Hemsley-Brown \& Oplatka, 2006). With this in mind, can projective techniques be used to explore HEl corporate brands and investigate the alignment between two related yet distinct concepts such as identity and image? Will researching corporate brands with the aid of projective techniques highlight the capabilities of different categories 
of projective techniques and provide guidance on how to embed the activities within other data collection methods. This in turn could clarify when and how to carry out the most appropriate projective techniques, which would be especially important for researchers and practitioners inexperienced with projective techniques and also practitioners with support on how to embed the activities within other data collection methods.

\section{Research Design}

The overall research aim of this study was to explore the capabilities of projective techniques, as a supplement to more traditional approaches, in helping to understand the different interpretations of a corporate brand and in particular its related identity and image. This study adopted a two-staged approach to the research design. The first stage initially took place at a university in the Rol while the second stage focused on a post-92 university in England. Both studies considered perceptions of the Universities' corporate brand and that of the Department/Faculty of Education, specifically teacher education. Initially, an explanation is provided for stage one, on methodological approaches adopted, traditional data collection tools and particular projective approaches utilised, followed by a brief discussion on the analysis and key findings. Similarly details for stage 2 are subsequently discussed together with key findings. The final section draws together these different foci and concludes with a discussion that primarily considers the advantages and disadvantages of utilising projective techniques in both stages.

\section{Stage One}

The key purpose of stage one was to explore perceptions of a University's corporate brand in the Republic of Ireland (Rol) together with its associated Faculty of Education. A critical case study drew on a cross-sectional survey within a quantitative paradigm. The questionnaire was heavily influenced by the work of Lages and Fernandes' (2005) and was supported by projective techniques as a supplement so as to gain insight into the students' perspectives being expressed in the more structured questions. In particular, the researchers explored students' interpretations of the corporate brand image, with a specific focus on brand values. These included sentence completion (Cohen, et al, 2008) in order to evoke both tangible and emotional components of the University's brand (Gutman and Miaoulis, 2003), compared to that of the competition and the Department of Education. In order to explore results from the sentence completion in more detail, respondents were asked to provide three words (association) to describe how they felt about the University and the Department.

A cohort of circa 250 Bachelor of Education (BEd) students, studying for a diploma in the Department of Education were targeted, all were from different specialisms in the University. This was a nonprobability sample (Cohen et al, 2008; Bryman and Bell, 2007) as it was targeting respondents in the knowledge that the sample would not represent universities more generally (Cohen et al, 2008). The total number of responses received was 85 , which, out of a total sample of circa 250, was disappointing. However, this was due to problems accessing the students through a 'gatekeeper' who had fallen ill for some weeks during which time many of the students had gone on placement. Data from the projective techniques was categorised into themes and 'units' (Saunders et al, 2009: 493) for this stage. Using coding adapted from Miles and Huberman (1994) a list of codes was developed particularly those key words / phrases that appeared to share similar emotions (Denscombe, 2003).

\section{Stage One - Findings}


The key purpose of this stage was to explore students' perceptions of the corporate brand. In order to understand if they understood the University's brand identity, and hence the brand image. Respondents were initially asked to complete the sentence "I came to the [University] because....". There were 82 comments recorded which were grouped into 11 key categories. By far the most popular response (48) was the popularity of the course and the fact that it was the only one available 'in the country'. Other comments related to the course included: 'It was my first choice', 'I heard [the University] was very student-friendly' and 'the only place that offered me a course that I was really interested in'. Other significant themes emerged, related to the University corporate brand, are highlighted with examples of comments, in table 4 below.

Table 4 Sentence completion: I came to the [university] because....

\begin{tabular}{|c|c|}
\hline Theme & $\begin{array}{l}\text { Number of } \\
\text { comments }\end{array}$ \\
\hline $\begin{array}{l}\text { Location } \\
\text { 'It was close by, in the West of Ireland; I liked the City' }\end{array}$ & 10 \\
\hline $\begin{array}{l}\text { Identity } \\
\text { 'I liked the atmosphere on campus; more welcoming and friendlier campus; } \\
\text { they have great sporting facilities' }\end{array}$ & 10 \\
\hline $\begin{array}{l}\text { Image } \\
\text { 'I wanted a good quality degree from a highly recognised college' } \\
\text { 'I wanted to engage in the best teacher education programme in Ireland' } \\
\text { 'Suited me best' }\end{array}$ & 9 \\
\hline
\end{tabular}

When respondents were asked to complete the sentence "I did not go to another University because....", of the 77 comments recorded most referred again to "no course that matched what I wanted' and the 'good teacher programme' at the University together with comments concerning its location. The questions were clearly too similar and this was not picked up in the pilot (table 5). However, there were further interesting comments concerning the identity and image of the University highlighted in table 6.

Table $5 \quad$ Sentence completion: I did not go to another university because....

\begin{tabular}{|l|}
\hline Identity \\
\hline 'I was lucky!' \\
'It seemed better than the other college' \\
'This seemed an easy going campus'
\end{tabular}




'I did not want to go to a "concrete built" campus'
'No interest in any place after seeing [University]'
'The campus of [University] is better'
'Besides [University] has a much better community'
'University] has a much superior campus'
'I did not like the campus in Dublin'
Image
'They didn't meet the high standard of [this University]'
'It did not have as good a reputation'
'This was the most recognised course in the area at the time'
'This University] has a great reputation'

Most significant during the analysis of the data were the three words that respondents used to complete the sentence: what three words come to mind when you think of the University? The emerging categories appeared to represent different levels of values discussed in the literature review (Lages \& Fernandes, 2005; Gutman \& Miaoulis, 2003; Durvasula et al, 2011; Harris \& de Chernatony, 2001). These results are summarised in table 6 , although numbers of responses have not been included due to the overall low response rate (each response was quite small). The breadth and depth of words were meaningful and those included in the table occurred at least twice while a few appeared more frequently including: friendly, fun, community.

Table 6 Association: what three words come to mind when you think of the University

\begin{tabular}{l} 
Values - functional (University) \\
$\begin{array}{l}\text { Good atmosphere, friendly, fun, welcoming, energetic/active, interesting, accepting, } \\
\text { great/excellent, big, beautiful, innovative/dynamic, positive, diverse, pleasant, efficient, } \\
\text { friends }\end{array}$ \\
\hline Values - functional (campus) \\
Amazing campus, facilities, sport, library, social life, modern, young
\end{tabular}




\begin{tabular}{|l|}
\hline Values - emotional (University/campus) \\
$\begin{array}{l}\text { The other home/feels like home, joyful, community, challenge, relaxed, excitement, } \\
\text { strength, together }\end{array}$ \\
\hline $\begin{array}{l}\text { Values - personal (end state) } \\
\text { experience, recognition, high achieving }\end{array}$ \\
\hline Values - functional (study) \\
Exams, degree, quality, teaching/teachers, professional, high standards, opinions \\
\hline Values - emotional (study) \\
Supportive, helpful, understanding, caring \\
\hline Negative comments \\
Unorganised, disrespectful, business, overhyped, politics, inefficient
\end{tabular}

Conversely, students were asked what three words came to mind when they thought of the Faculty of Education and although some of these were positive, the question seemed to elicit a number of negative comments, using many different words, and phrases in some cases (rather than the three words requested). Table 7 demonstrates a number of positive and negative examples of significant quotations extracted from each of the Faculty responses (relative to the number of responses). Most of these words are powerful, especially the negative comments, and suggest the emergence of an undesirable image of the Department of Education compared to a far stronger University corporate brand image.

Table $7 \quad$ Word association: what 3 words come to mind when you think of the Department of Education....

\begin{tabular}{|l|l|}
\hline Positive quotes & Faculty \\
\hline Passion, Caring, noble & Architecture \\
\hline Professional, passionate, dedicated & Architecture \\
\hline Boring, essays, interesting, enlightening & Architecture \\
\hline Professional, helpful, understanding & Engineering \\
\hline Helpful, resourceful, supportive & Engineering \\
\hline Professional, informative, enjoyable & Modern Languages \\
\hline Communication, friendship, critical thinking & Physical Education \\
\hline Teaching, influential, cooperation & Physical Education \\
\hline Friendly, caring, professional & Science with Biology \\
\hline
\end{tabular}




\begin{tabular}{|l|l|}
\hline Renowned, integrated, success & Science with Biology \\
\hline Heterogeneous - varied but compassionate & Science with Biology \\
\hline Friendly, supportive, fair & Science with Physics \\
\hline Negative quotes & Faculty \\
\hline Don't think they care much about students & Architecture \\
\hline Fear, exam's, difficult & Architecture \\
\hline Hypocritical, tedious, essays & Architecture \\
\hline Disconnected & Engineering \\
\hline Unfair, ignorant, cold & Engineering \\
\hline Out of touch, arrogant, obtuse & Modern Languages \\
\hline Boring, complicated, volume & Physical Education \\
\hline Unreliable, inconsistent, untransparent & Physical Education \\
\hline Boring, outdated, egotistical & Science with Biology \\
\hline Egocentric, incoherent, disjointed & Science with Biology \\
\hline Hard work, idealistic, monotonous & Science with Biology \\
\hline Academic, slightly unrealistic, standards & Science with Physics \\
\hline
\end{tabular}

Subsequently, a disconnect between the University and Department was highlighted in the quantitative results, including their respective values, but the reasons behind this were not apparent. However, the qualitative projective techniques positioned at the end of the questionnaire provided a far deeper insight into the students' responses to the questionnaire, notwithstanding the low response rate. This disconnect became much clearer through the use of sentence completion and word association and in particular, occurred once the students joined the Department.

\section{Stage Two}

The key purpose of stage two was to compare perceptions of the corporate brand in a post-92 university in England and perceptions of the University's Faculty of Education. A revelatory case study (Yin, 2009) approach was adopted which drew on primary sourced data within a qualitative paradigm. Data collected was through semi-structured interviews with key employees within the University (brand identity) and focus groups with students (brand image). Semi-structured interviews allowed for an 'elaborate in-depth response' (Gillham, 2000, p. 19) while focus group dynamics produced data and insights not found in individual interviews (Flick, 2006), for example, particular values that respondents might hold (Murdaugh et al, 2000). Building on experiences from stage one the key projective technique used was metaphors (Hofstede, 2007; Farook, 2013) but, rather than projecting a person metaphor (Davies et al, 2004), a car was chosen in order to explore if an inanimate object would reveal more depth and understanding. Thus, respondents were asked for types of car for both the University and the Faculty. This allowed them to associate the University/Faculty as an entirely different stimuli (Hofstede, 2007; Farook, 2013; Oswick \& Montgomery 1999; Pich et al, 2018). 
Employee respondents were selected purposively for the interviews according to their involvement with students and other external stakeholders for example. Thus in total, fourteen individual face-toface interviews were conducted. This comprised four senior faculty managers, two academic faculty (middle) managers, six lecturers and two marketing managers in the University. Three focus groups held involved seventeen teacher trainees drawn across those studying: primary (junior) school education (6); secondary (senior) school education (7); continuing education (4). In order to obtain in-depth, qualitative insights (Gillham, 2000; Yin, 2009) individual questions mirrored those posed to staff interviewed where possible. Table 8 highlights respondents, their role, and code while table 9 highlights the students who participated in the focus groups.

Table 8

\section{Coding of respondents}

\begin{tabular}{|l|c|}
\hline Role & Code \\
\hline Senior Manager, Faculty & SF2 \\
\hline Senior Manager, Faculty & SF3 \\
\hline Senior Manager, Faculty & SF4 \\
\hline Senior Manager, Faculty & SF5 \\
\hline Academic Manager, Faculty & AF2 \\
\hline Academic Manager, Faculty & AF3 \\
\hline Lecturer, Faculty & LF1 \\
\hline Lecturer, Faculty & LF2 \\
\hline Lecturer, Faculty & LF3 \\
\hline Lecturer, Faculty & LF4 \\
\hline Lecturer, Faculty & LF5 \\
\hline Lecturer, Faculty & LF6 \\
\hline Marketing Manager, University & MMU1 \\
\hline Marketing Manager, University & MMU2 \\
\hline
\end{tabular}

Table 9 Details of focus groups

\begin{tabular}{|l|c|l|}
\hline Student type & $\begin{array}{c}\text { Number in } \\
\text { group }\end{array}$ & Respondents' characteristics \\
\hline Primary education & 6 & 1 male \\
\hline Secondary Education & 2 & $\begin{array}{l}1 \text { male (SEC1) } \\
1 \text { female (SEC2) }\end{array}$ \\
\hline Masters & 9 & $\begin{array}{l}\text { All female; } 2 \text { of these international } \\
\text { students }\end{array}$ \\
\hline
\end{tabular}

The topics covered in both the individual interviews and focus groups were related to respondents' perceptions of the corporate brand and included: identity, image, vision, values and communications. Qualitative projective techniques were incorporated as they helped respondents to reveal hidden perceptions, particularly with more abstract topics such as branding (Boddy, 2005; Pich \& Dean, 2015). This was particularly the case when respondents were questioned about the University brand as they 
were only really able to articulate the more visual aspects of the brand, such as the logo and buildings, rather than denoting something more meaningful to which they could make a connection (Chapleo, 2011; Clayton, 2012). Instead of utilising the person metaphor (Davies et al, 2004) to discover respondents' views on identity and image, respondents were asked what model of car sprang to mind for both the University and the Faculty. These questions attracted interesting responses and the researcher found the metaphor projective technique a particularly helpful approach in trying to unravel the components of a corporate brand from both the internal perspective (identity) and the external perspective (image).

Following transcription of the data a form of 'indexing and sorting' (Spencer et al, 2014: 278) was adopted and meant that data could constantly be revisited in order to establish 'themes or interconnections that recur between the units and categories that are emerging' (Denscombe, 2003). In order to really understand different individuals' perceptions, quotations by participant and by theme (Spencer et al, 2014) were entered into matrices to provide 'a firm foundation' (Spencer et al, 2014: 284) on which to build an analysis of the findings. This proved to be a really useful approach for the projective techniques particularly as comparisons had to be drawn between the different groups of respondents within the case study (Lewis and McNaughton Nicholls, 2014); different perceptions from both students and staff was clearly highlighted.

\section{Stage Two - Findings}

This research aimed to examine the different interpretations of a corporate brand, and its implementation in a post-92 university. In order to understand interpretations of a brand image from an external perspective it was important to explore initially perceptions of brand identity inside the University. Comparisons between employees' interpretations of the brand identity and the students' interpretations of the brand image were next explored. This took into consideration the context of a Faculty of Education, and more specifically teacher education, which was the primary area for the research.

\section{University brand identity and image}

When respondents answered the question 'do you feel the University has a corporate brand and how would you describe it?' comments were not particularly insightful (table 10). This was partly due to difficulties in applying the concept to education 'when it comes to education I'm not about branding' (AF3). Comments were far more insightful when respondents responded to 'what sort of car is the University?' For example, some respondents perceived the car as something 'slightly upmarket' (MMU1) while others thought the University car would be, for example, a 'BMW'.

Further exploration suggested that the University was viewed as being average or lacking in distinction. For example, LF6 referred to post-92 universities in the region and the fact that it was hard for the University to have a corporate brand 'because they've all got to have the basics in place haven't they?' and the fact that they were all 'much of a muchness' (LF1). SF4 felt that the University was 'stuck in the middle...trying to do everything for everybody' in terms of competing with other universities for the same students. This supported one of the findings from the interview questions with students who pointed to a 'lack of that recognition that we have different traits and needs....'. However, AF3 thought that the University was aspiring to be different, but when asked in what way 'I'd have to think about that long and hard' was the reply. Further comments from both employees and students concerning their choice of car which relate to this lack of differentiation, are highlighted in table 11. 


\begin{tabular}{|l|l|}
\hline Quote & Participant \\
\hline $\begin{array}{l}\text { '...it might be one of those reliable Japanese } \\
\text { jobs' }\end{array}$ & LF6 \\
\hline $\begin{array}{l}\text { 'A Golf....reliable, trustworthy, not cheap, solid, } \\
\text { lasts forever' }\end{array}$ & AF3 \\
\hline $\begin{array}{l}\text { 'we wouldn't be seen as anything } \\
\text { vintage....more of a reasonably modern reliable } \\
\text { car' }\end{array}$ & LF4 \\
\hline $\begin{array}{l}\text { 'big, fairly bland but fairly reliable people } \\
\text { carrier that does everything you need it to do } \\
\text { without being too flash' }\end{array}$ & LF3 \\
\hline $\begin{array}{l}\text { 'something sound and reliable like a Ford Focus } \\
\text { maybe' }\end{array}$ & SF2 \\
\hline $\begin{array}{l}\text { 'fairly reliable and bland.... a family-oriented } \\
\text { saloon' }\end{array}$ & SF4 \\
\hline $\begin{array}{l}\text { 'a bit sporty, a bit 'here I am' but also tried and } \\
\text { tested, reliable and adaptable' }\end{array}$ & SF5 \\
\hline 'its reasonable quality, its reliable'. & LF2 \\
\hline $\begin{array}{l}\text { 'Something German, not overly expensive but } \\
\text { reliable' }\end{array}$ & Primary education students \\
'Like a mid-range reliable car' \\
'Any type of German car, it's pretty reliable' \\
'Very reliable, very helpful' \\
\hline $\begin{array}{l}\text { '...it might be one of those reliable Japanese } \\
\text { jobs' }\end{array}$ & LF6 \\
\hline
\end{tabular}

Table 11

The University car - stuck in the middle

\begin{tabular}{|l|l|}
\hline Quote & Participant \\
\hline 'Probably mid-range...fairly high spec...a salesman's or rep's car....' & LF1 \\
\hline 'We can't pretend to be a Rolls Royce...we're not a Skoda either' & SF3 \\
\hline '...more along the lines of a Peugeot, a mid-range car' & MMU2 \\
\hline '...not cutting edge, but not an old banger, somewhere in the middle' & SEC1 \\
\hline '...middle of the range, nothing too flash but not an old banger' & Primary student \\
\hline
\end{tabular}

Faculty Identity and Image

When the same groups of respondents responded to 'what sort of car is the faculty?' answers were quite different, as can be seen in table 12. For example, SF3 did not believe that the Faculty, when it came to the corporate brand, would be a priority for the University. Staff respondents related the "values" of the Faculty as being important to the quality and importance of the partnerships they held with local schools and colleges and the fact that the Faculty [as a car] is 'viewed as something slightly different' (SF4) to that of the University. The same respondent felt that if partner organisations were to draw on different models of car for different programmes 'some of our partners may now be seeing us as a hybrid...new technology...quite ahead of the field' (SF4). In addition, and making reference to a model of car SF4 thought that applicants for teacher training programmes would see the Faculty 'as 
top of the range and actually quite an exclusive model'. LF6 thought the "Faculty car" would be ' $a$ high-end Honda' because there is an emphasis on producing innovative and creative teachers.

Table 12

Metaphor: what sort of car is the faculty?

\begin{tabular}{|l|l|}
\hline Quote & Participant \\
\hline 'A low-end BMW or an Audi...' & LF1 \\
\hline 'Something higher spec [than the University]' & SF2 \\
\hline $\begin{array}{l}\text { 'More streamlined [than the } \\
\text { University]...probably with less parts' }\end{array}$ & AF2 \\
\hline $\begin{array}{l}\text { 'Good performance, but not expensive, and } \\
\text { accessible' }\end{array}$ & SF4 \\
\hline $\begin{array}{l}\text { 'Feels powerful...something like a } \\
\text { Cadillac...large and distinctive' }\end{array}$ & LF4 \\
\hline $\begin{array}{l}\text { 'VW Golf GTi...something comfortable and } \\
\text { supportive' }\end{array}$ & AF3 \\
\hline $\begin{array}{l}\text { '...tech savvy...not too flash.... a sort of Guardian } \\
\text { reader's car' }\end{array}$ & LF2 \\
\hline 'a turbo-charged Mini' & SF3 \\
\hline $\begin{array}{l}\text { 'Its more the sort of the reputation of VW than } \\
\text { the actual car }\end{array}$ & MMU2 \\
\hline $\begin{array}{l}\text { '...something like a Porsche because of how fast } \\
\text { moving it is...' }\end{array}$ & SF5 \\
\hline '...a Lotus Elise, a really sporty nice car' & SEC1 \\
\hline
\end{tabular}

Further probing revealed that the University corporate brand would not be 'a supportive, cooperative brand' (SF3), a culture the respondent associated with the Faculty of Education. A senior manager external to the Faculty (MMU1), described the "Faculty car" as something reliable and safe but that it would not 'set the world on fire'. The MA students, had trouble viewing the Faculty 'as a separate entity' although one student thought that it would be a car that once inside would be 'much bigger and perhaps has more bells and whistles than on the outside'. This may have been due to the Faculty having a number of different areas described by LF3 as being:

'...really complicated underneath the bonnet, on the surface it all looks straightforward the way we present it to the trainees'

When LF4 was asked what car the Faculty might be she compared the Faculty and teacher education as being 'slightly different things' and teacher education 'as something with more of a history to it' which was evolving at a speed much faster than education more generally. For example, LF4 and SF3 viewed their programmes as having 'a brand of its own...' (SF3). This suggests different identities for different programmes. For example, LF4 felt that teacher training courses were the Faculty's 'safety net' and described them as 'something sturdy... a pick-up truck'. This was supported by documentation from partners who were impressed with how the students were ready to 'hit the ground running' when they joined schools and colleges. Further, this clearly aligned with the views of students who, during the interview questions, expressed how happy they were to secure a place on the teacher training programmes 'It boosts your self-esteem, you feel a bit special' and 'nailed it!' and when they actually joined their particular programmes 'it's certainly surpassed my expectations'.

In summary, the projective techniques utilised in stage two not only expanded on data collected through more traditional qualitative methods but also substantiated the findings from documentation 
and interviews. Through the metaphor approach employees and students expressed a lack of association to the University's corporate brand and related values, and associated themselves far more closely to the Faculty rather than the University.

\section{Discussion}

The overall research aim of this study was to assess the capabilities of projective techniques, as a supplement rather than a replacement to more traditional approaches, in gaining a deeper insight into complex university corporate brands. To understand different interpretations of a corporate brand, the research conducted was in in two stages, at an international University and a post-92 University in England. This study demonstrates that projective techniques represent a series of pragmatic tools, which allow respondents to express their deep-seated attitudes, behaviours, feelings and personal perspectives in regards to corporate brands through the theoretical lens of brand identity and image (Boddy 2005; Denzin and Lincoln 2017; Escribanoa et al, 2020; Gordon 1999; Gordon and Langmaid 2008; Janetius et al, 2019; Pich et al, 2018). Indeed, this study reveals that projective techniques can provide access to the private conscious and unconscious inner-world of respondents (Boddy 2004; Vince and Broussine 1996) by delving beneath the surface of explicitly stated attitudes, associations and perceptions (Bond and Ramsey 2010; Day 1989; Denzin and Lincoln 2017; Gordon 1999; Gordon and Langmaid 2008).

This study concurs that projective techniques can be used to reveal rich insight ascribed to different typologies of brands (De Carlo et al, 2009; Donoghue, 2000; Hofstede, 2007; Jiménez-Barreto et al, 2020; Moutinho et al, 2007; Prayag 2007; Pich et al, 2018; Pich et al, 2015; Tantiseneepong et al, 2012). Further, this study focuses on corporate brands which remains an under-explored typology, particularly in the context of Higher Education Institutions (HEIs). In addition, this study demonstrates the elicitation capabilities of using projective techniques inside an organisation to explore corporate brands from an employee perspective. This represents a neglected area of study as existing research tends to focus on using projective techniques to investigate brands from an external customer/consumer perspective. We will now discuss each stage and demonstrate that projective techniques are appropriate to investigate HEls as they uncovered the multi-layered, multi-faceted and complex nature of corporate brands.

\section{Sentence Completion and word association (stage 1)}

Through the use of the sentence completion projective technique (Escribanoa et al, 2020; Gronhoj \& Gram 2020; Hofstede et al, 2007; Janetius et al, 2019; Soley \& Smith 2008), it was established that by far the most prevalent reason student respondents had chosen the Rol University was the popularity of the course and the fact that it was the only one available in the country. This projective technique therefore allowed respondents to describe how they interpreted the University and the Department (Chandler and Owen, 2002; Escribanoa et al, 2020; Fisher, 2010; Gronhoj \& Gram 2020; Hofstede et al, 2007; Janetius et al, 2019; Soley \& Smith 2008). Thus the findings from the qualitative projective techniques demonstrate the University had secured a strong corporate brand image (Kapferer, 2012), in the eyes of its external stakeholders, through the delivery of a clear brand identity. However, findings from the word association projective technique were far more emotionally-driven (Kay, 2001; Donoghue, 2002) as it appeared to allow students to express their feelings in more depth. So few comments were negative and those that were positive were powerful which suggests a positive brand image can be a key driver in influencing a student to attend a particular university (Gutman \& Miaoulis, 2003). Further, this projective technique revealed that the physical and emotional elements of the University are providing the students with a network of linkages (Gutman \& Miaoulis, 2003) and a holistic experience (Kotler et al, 2009. For example, the findings demonstrate that students do have important values (Harris and de Chernatony, 2001; Uggla, 2006) which were possible to categorise in 
the analysis into functional values (Harris and de Chernatony, 2001), emotional values (Balmer \& Liao, 2007), desirable end states (Durvasula et al, 2011; Lages \& Fernandes, 2005) and terminal values (Lages \& Fernandes, 2005; Rokeach, 1973). Indeed, emotional values that students attribute to a corporate brand are those that give them an important sense of identity in the relationship they hold with the University (Balmer \& Liao, 2007). This implies that the University holds a unique position in the marketplace (Hatch and Schultz, 2001; Jevons, 2006) and is clearly doing its job in differentiating the Department's offer (Temporal, 2002).

Hence, the sentence completion projective technique confirms that 'the interviewee is given an incomplete sentence, story, argument or conversation, and asked to finish it, and it is generally known to be a structured-indirect way of investigating the whys of a situation' (Gronhoj and Gram 2020:9). However, while Hofstede (2007) and Farook (2013) claim that sentence completion and word association share similarities, it appears not to be the case in this study as findings from the word associations were far deeper but importantly they substantiated findings from the sentence completion. In particular, the incompatibility between the University and the Department revealed how perceptions can transpire over time (Roper and Fill, 2012) as despite initial positive perceptions from the respondents, an incompatibility emerged between the University and Department suggesting that there were unmet expectations once students joined the Department. Although the students attributed positive words to the Department, their number was slightly less than the deep and powerful negative words highlighted. This suggests an incompatibility with the Departments' values (Harris \& de Chernatony, 2001; Timmor \& Rymon, 2005) and it could be argued that the University is not delivering what it has promised (Gutman \& Miaoulis, 2003; Balmer \& Liao, 2007).

\section{Metaphors and Annotation (stage 2)}

Although results from the projective techniques were insightful in the first study, and accentuated the lack of probing in questionnaires, it was still difficult to understand why respondents felt in such ways. As with the first stage, projective techniques were utilised as a supplement in stage two, rather than replacing the more traditional methods. This is an important point as respondents were not completing a questionnaire, as in study one, but participating in either an interview or focus group. Questions were therefore generally more in-depth and included topics relating to a corporate brand such as vision, values, culture, personality, relationships. All of these topics are abstract and difficult to articulate and by utilising the metaphor projective technique it was possible to explore corporate brand identity (internally) and corporate brand image (externally).

The metaphor approach (Farook, 2013; Hofstede, 2007; Oswick \& Montgomery 1999; Pich et al, 2018) was hugely useful in adding more depth to respondents' answers particularly in terms of exploring the alignment of brand identity and image. Therefore, results in the second study were very different particularly in terms of the Faculty of Education, which respondents viewed much more positively than the University's corporate brand. It was not just the types of cars respondents gave that were insightful but also the related comments. Further, incongruity emerged during the interview questions, and by utilising the metaphor projective technique it was possible to explore this lack of distinction further. For example, both employee and student respondents clearly understood the visual aspects of the University's corporate brand such as logos, colours etc, but strategic perspectives, such as points of differentiation, revealed a more neutral perspective. While Fetscherin and Usunier (2012) suggest that a corporate brand is an intrinsic part of everyday life, employee respondents in particular appeared unclear as to the University's identity except for this point of reliability. As claimed by a number of authors (Abratt \& Kleyn, 2012; He \& Balmer, 2007; Roper \& Fill, 2012) this may be due to a lack of clarity as to exactly what it is that the University is seeking to be. Importantly, 
this lack of distinction substantiated a key finding from the interview questions in that students felt strongly that their needs were not being met. According to a number of authors (Hatch \& Schultz, 2001; Jevons, 2006), the University is therefore not positioning itself in the minds of different target markets. Hemsley-Brown \& Gonnawardana (2007) point to different target markets, particularly niche markets, belonging to different departments.

By asking respondents, what type of car the Faculty would be, so many interesting comments emerged. Respondents used powerful words that were different to that attributed to the University due primarily due to the faculty co-creating a vision for a teacher and related values with their partner organisations (schools and colleges). This aligns with Chapleo (2010) and Harris \& de Chernatony (2001) who maintain that a corporate brand will be more successful if the values created correspond with the emotional needs of their stakeholders. This study demonstrates the depth of the relationships held with partners and, as mentioned by (Balmer, 2008), the confidence they place in staff to ensure that trainee teachers are fully prepared and able to cope with a changing environment.

Utilising the metaphor technique therefore drew out a final key finding in this research study and the emergence of "sub-brands" (Chapleo, 2007; Hemsley-Brown \& Goonawardana, 2007), brought about by ongoing changes in the teacher education sector and differences between cultures (De Chernatony \& Cottam, 2006) in the University, the Faculty and within the Faculty. These sub-brands are the different teacher training programmes that appear to have their own identity, values and image as they are catering for very specific target markets. It is the concept of image that adds particular importance to the sub-brands (Chapleo, 2007), in terms of the staff that design and deliver the courses and the relationships they hold with different stakeholders. More importantly is the fact that these distinct pockets of specialities may provide the very source of competitive advantage required for a post-92 university seeking to hold a corporate brand with a competitive edge (Abratt \& Kleyn, 2012; Anctil, 2008; Chapleo, 2010; Hemsley-Brown \& Oplatka, 2006). These findings clearly emphasise new and important knowledge that we have framed against the projective techniques literature and developed into a framework entitled the projective technique planning matrix outlined in table 13.

Table 13

Updated Projective Technique Planning Matrix

\begin{tabular}{|c|c|c|c|}
\hline Data Collection & Categories & Examples & Probes-Prompts \\
\hline $\begin{array}{l}\text { Projective techniques } \\
\text { can be used to } \\
\text { complement } \\
\text { interviews, focus group } \\
\text { discussions and open- } \\
\text { ended } \\
\text { questionnaires/surveys. } \\
\text { Researchers should be } \\
\text { mindful of how to } \\
\text { collate and organise } \\
\text { expressions generated } \\
\text { from projective } \\
\text { techniques prior }\end{array}$ & Association & $\begin{array}{l}\text { Finishing stories, sentence } \\
\text { completion or drawings } \\
\text { including speech and } \\
\text { thought bubbles. } \\
\text { Compose a story, narrative, } \\
\text { mould a sculpture, use of } \\
\text { LEGO, paint a picture, collage } \\
\text { from magazines or } \\
\text { newspapers }\end{array}$ & $\begin{array}{l}\text { It is important to } \\
\text { recognise that } \\
\text { researchers may } \\
\text { need to probe } \\
\text { respondents to } \\
\text { reveal meaning } \\
\text { behind the } \\
\text { expressions } \\
\text { generated from the } \\
\text { projective } \\
\text { techniques. } \\
\text { Otherwise, rich } \\
\text { insight may not be } \\
\text { captured and the }\end{array}$ \\
\hline
\end{tabular}




\begin{tabular}{|c|c|c|c|}
\hline $\begin{array}{l}\text { analysis and to ensure } \\
\text { projects are organised } \\
\text { and findings are } \\
\text { catalogued. }\end{array}$ & Choice ordering & $\begin{array}{l}\text { Rank product benefits or } \\
\text { groups of pictures from } \\
\text { favourite to least favourite. }\end{array}$ & $\begin{array}{l}\text { meaning may } \\
\text { reveal more about } \\
\text { the researcher than } \\
\text { insights generated }\end{array}$ \\
\hline $\begin{array}{l}\text { Irrespective whether } \\
\text { researchers adopt one, } \\
\text { two or multiple }\end{array}$ & Expressive & $\begin{array}{l}\text { Role-playing, drawing, } \\
\text { drama, dance walk-and-talk } \\
\text { interviews, observations. }\end{array}$ & $\begin{array}{l}\text { from the projected } \\
\text { expressions. } \\
\text { However, }\end{array}$ \\
\hline $\begin{array}{l}\text { categories, researchers } \\
\text { should ensure each } \\
\text { participant has an } \\
\text { individual booklet to } \\
\text { record the generated } \\
\text { expressions. This will } \\
\text { aid consistency and } \\
\text { ensure the data } \\
\text { collection methods are } \\
\text { carried out in a } \\
\text { professional manner. }\end{array}$ & Metaphors & $\begin{array}{l}\text { Connotations linked to the } \\
\text { topic under study. This } \\
\text { creative technique has no } \\
\text { boundaries. Respondents } \\
\text { can be asked to link topic } \\
\text { under study with food, } \\
\text { animals, car parts, cartoons }\end{array}$ & $\begin{array}{l}\text { not use subjective, } \\
\text { emotive probing to } \\
\text { elicit additional } \\
\text { insight otherwise } \\
\text { this could lead the } \\
\text { respondents and } \\
\text { bias the findings. }\end{array}$ \\
\hline
\end{tabular}

Source: Expanded from Hofstede, 2007; Porr et al, 2011; Farook, 2013; Oswick and Montgomery 1999; Pich et al, 2015; Pich et al, 2018

The projective technique planning matrix builds on table 1 and now includes the metaphor as a recognised and valuable approach with clear advantages, particularly in the exploration of corporate brands. In addition, the projective technique planning matrix provides researchers both experienced and those new to projective techniques with guidance on how to embed the activities within surveys, focus groups and interviews, and examples of the different types of activities and the importance of probing respondents to expand and elaborate on their projected expressions and associations. Probing is a crucial stage of conducting projective techniques and will enable the researcher to interpret the perceptions and opinions linked to each expression based on the meaning generated by the respondent rather than the perceptions and opinions of the researcher (Farook, 2013; Pich \& Dean 2015; Pich et al, 2018). This in turn will strengthen the validity and transparency of the interpretive process.

\section{Conclusion}

The overall purpose of this research study was to explore the capabilities of qualitative projective techniques as a supplement to traditional approaches, in helping to understand the different interpretations of corporate brands, within an international context. What has emerged from this research are implications for both theory and practice. In terms of theoretical implications, this research clearly highlights that qualitative projective techniques can be utilised as a supplement for both quantitative and qualitative approaches, in order to uncover far deeper insights and increase our understanding of corporate brand identity and corporate brand image. This research adds to the limited knowledge on how qualitative projective techniques can be utilised in exploring corporate brand identity, associated values and image in the context of HEls. For example, it was through word association and sentence completion in stage one that respondents were better able to express, how they interpreted the University and the Department (Fisher, 2010; Chandler and Owen, 2002) and most importantly their tacit values (Doherty \& Nelson, 2010). Brand values in a university is an under- 
explored area (Waerass, 2008) whereas this research provides some insight into the importance of aligning corporate brand values with different stakeholders as these could be the very source of a competitive advantage (Balmer \& Gray, 2003; Hatch \& Schultz, 2003). Further, although a number of authors maintain there are similarities between word association and sentence completion (Hofstede, 2007; Farook, 2013) this research highlights clear differences. For example, the sentence completion data indicated strong, positive perceptions of the University's image and overall the Department (Hofstede, 2007; Pich \& Dean, 2016). Conversely, it was the word association technique in this study that uncovered a strong disconnect between the University and Department, as students were clearly able to project their own feelings on to the Department with the use of powerful words. While Will et al, (1996) question the reliability of the word association technique, this finding adds far more robustness and meaning to the quantitative data collected as it was the qualitative comments associated with "values" through the projective techniques, not the Likert scales, which substantiated this finding.

Further, although qualitative projective techniques employed were utilised as a supplement in the second study, the rich data collected clearly supported and enhanced similar data collected through documentation and the semi-structured interviews. For example, when discussing perceptions of cars employee respondents considered external stakeholders and their perceptions. This aligned with documentation received from schools and colleges (Balmer 2008; Chapleo, 2011; Clayton, 2012). Projective techniques applied also contributed to the limited understanding of corporate brand identity and its alignment with brand image (Cornelissen \& Elving, 2003), particularly in the context of $\mathrm{HE}$ (Pich et al, 2018). For example, employees and students clearly associated themselves more closely to the Faculty rather than the University (Steiner, Sundström \& Solbakk, 2008). A key finding in this study was the emergence of sub-brands (Chapleo, 2007) that noticeably highlights the importance of employing projective techniques with employees inside organisations, which research has neglected to explore to date. The theoretical contributions highlighted have enabled us to develop the Projective Technique Planning Matrix (table 13) that can be used by researchers both inexperienced with projective techniques and also practitioners with support and guidance on how to embed the activities within other data collection methods. Furthermore, the projective technique planning matrix provides researchers and practitioners with examples of the different types of activities and reinforces the importance of probing participants to expand and elaborate on their projected expressions and associations (Farook, 2013; Pich \& Dean 2015; Pich et al. 2018).

\section{Practical outcomes}

In terms of practical outcomes-implications, this study equips practitioners with pragmatic insight, guidance and capabilities in the use of projective techniques and reaffirms that projective techniques can be seen as a series of devices that allow respondents to articulate sub-conscious, repressed or often withheld feelings, opinions and perceptions by projecting these onto another character (Boddy 2005; Denzin and Lincoln 2017; Gordon and Langmaid 2008; Gronhoj and Gram 2020). For example, this study demonstrates that projective techniques are useful in gathering deep insights into employees' perspectives as it puts them at ease in a non-intrusive way, so that evidence can be teased out on how people interpret the corporate brand which provided us with access to unspoken values.

While both stages of the research contained few qualitative projective techniques, this study clearly demonstrates that even if used as a supplement these techniques not only enhance the depth of the data collected from traditional approaches, but also increases our understanding of corporate brands in different and sometimes complex contexts. For example, this study shows that sentence completion can be limiting, particularly if included as part of a quantitative study, although its use as a probing tool is highlighted. The addition of word associations in the quantitative study allowed for far more emotion-driven responses in the first study which substantiated the initial findings from the sentence 
completion technique. Further, the word association technique in the first study also identified an incompatibility over time, as once students joined the department, expectations were not met.

Finally, the metaphor projective technique in the second study aided respondents to think beyond the visible aspects of a brand identity and image which highlighted disconnect between the University and the Faculty. Unlike the first study both employees and students in the second study viewed the Faculty more positively than the University due to the co-creation of teacher-related values and strong relationships held with key stakeholders. In the second study the metaphor projective techniques employed substantiated documentary evidence collected from key stakeholders and hence the emergence of sub-brands. Finally, practitioners can utilise the developed Projective Technique Planning Matrix to assist with planning, integrating and implementing projective techniques into their market research projects to capture attitudes, perceptions and feelings ascribed to different typologies of brands from internal and external perspectives.

\section{Future research}

- Future research could focus on applying the Projective Technique Planning Matrix to assess its usability as a pragmatic framework to assist inexperienced and experienced individuals with projective techniques during the planning, research and analysis stages of research. In addition, researchers should aim to expand this framework with additional examples, techniques or advice for researchers, practitioners and students and this will provide more insight and understanding into projective technique research and analysis.

- Further investigations could be conducted into the limitations of using projective techniques in open-ended surveys/questionnaires as existing studies have tended to focus on the inclusion of projective techniques within focus group discussions and other methods may be as efficient and effective.

- Future research should expand insight into the elicitation capabilities of the use of projective techniques in mixed-method studies and assess the usefulness and limitations of online projective techniques.

- Researchers should continue to push the boundaries of projective techniques and use them to investigate perceptions, associations and imagery linked to organisations, brands, services and people across disciplines. This multi-disciplinary approach may reveal new techniques and challenge existing activities.

\section{Limitations}

This study has provided a number of key insights concerning the usefulness of qualitative projective techniques in a $\mathrm{HE}$ context and the contribution these might make in developing our understanding of corporate brands and related identities and images. It is however, acknowledged that data obtained was from only two institutions and in the very specific context of teacher education. Nonetheless, as the focus was on depth of understanding rather than breadth, this case study provides the opportunity to explore corporate branding in a context not previously researched and a phenomenon was uncovered that is considered revelatory in nature (Yin, 2009). Further, the low response rate in the quantitative study is acknowledged, and the numbers from different disciplines, could result in bias. However, an extraordinary situation occurred, not due to a no-response issue, and there is therefore scope to conduct future research utilising similar methods in a similar setting. 


\section{References}

Aaker, D. and Joachimsthaler, E. (2002). Brand Leadership. London: Simon \& Schuster UK Ltd.

Abratt, R., and Kleyn, N. (2012). Corporate identity, corporate branding and corporate reputations: reconciliation and integration. European Journal of Marketing, 46, 7-8, 1048-1063.

Alves $\mathrm{H}$, Raposo, $\mathrm{M}$ (2010). The influence of university image on student behaviour. International Journal of Education Management, 24, 1, 73-85.

Anctil, E.J. (2008). Marketing and advertising the intangible. ASHE Higher Education Report, 34, (2), 31-47.

Argenti, P.A. and Druckenmiller, B. (2004). Reputation and the corporate brand. Corporate Reputation Review, 6, 368-74.

Balmer, J. M. T. and Gray, E. R. (2003). Corporate brands: what are they? What of them? European Journal of Marketing, 37, 7/8, 2003.

Balmer, J. M. T. and Liao, M. N. (2007). Student corporate brand identification: an exploratory case study. Corporate Communicatons: An International Journal, 12, 4, 356-375.

Balmer, J. M. T. (2008). Identity based views of the corporation: insights from corporate identity, organisational identity, social identity, visual identity, corporate brand identity and corporate image. European Journal of Marketing, 42, 9-10, 879-906.

Barbour, R. (2007). Doing Focus Groups. London, England: SAGE.

Boddy, C. (2004). From brand image research to teaching assessment: using a projective technique borrowed from marketing research to aid an understanding of teaching effectiveness. Quality assurance in Education, 12, 2, 94-105. 
Boddy, C. (2005). Projective techniques in market research: valueless subjectivity or insightful reality? A look at the evidence for the usefulness, reliability and validity of projective techniques in market research. International Journal of Market Research, 47, 3, 239-54.

Bond, D. and Ramsey, E. (2010). The role of information and communication technologies in using projective techniques as survey tools to meet the challenges of bounded rationality. Qualitative Market Research: An International Journal, 13, 4, 430-440.

Bryman, A. and Bell, E. (2007). Business Research Methods, second edition. Oxford University Press, New York.

Chandler, J. and Owen, M. (2002). Developing Brands with Qualitative Market Research. Sale, London.

Chapleo, C. (2007). Barriers to brand building in UK universities. International Journal of Nonprofit and Voluntary Sector Marketing, 12, 23-32.

Chapleo, C. (2010). What defines "successful" university brands? International Journal of Public Sector Management, 23, 2, 169-183.

Chapleo, C. (2011). Exploring rationales for branding a university: should we be seeking to measure branding in UK universities. Journal of Brand Management, 18, 6, 411-422.

Chapleo, C. (2015). An exploration of branding approaches in UK universities. International Journal of Nonprofit and Voluntary Sector Marketing, 20, 1-11.

Clayton, M. J., Cavanagh, K.V. and Hettche, M. (2012). Institutional branding: a content analysis of public service announcements from American universities. Journal of Marketing for Higher Education, 22, 2, 182-205.

Cohen, L. Manion, L. Morrison, K. (2007). Research Methods in Education, sixth edition. Routledge, New York.

Cornelissen, A. and Elving, F. (2003). Managing corporate identity: an integrative framework of dimension and determinants. Corporate Communications: An International Journal, 8, 2, 114-120.

Cretu, A. E. and Brodie, R. J. (2007). The Influence of Brand Image and Company Reputation Where Manufacturers Market to Small Firms: A Customer Value Perspective. Industrial Marketing Management, 36, 2, 230-240.

Croxford, L. and Raffe, D. (2015). The iron law of hierarchy? Institutional differentiation in UK higher education. Studies in Higher Education, 40, 9, 1625-1640.

Davies, G. and Chun, R. (2002). Gaps Between the Internal and External Perceptions of the Corporate Brand. Corporate Reputation Review, 5, 2-3, 144-158.

Davies, G. Chun, R. da Silva, R. V. and Roper, S. (2004). A corporate character scale to assess employee and customer views of organisation reputation. Corporate Reputation Review, 7, 2, 125146.

Day, E. (1989). Share of Heart: What is it and how can it be measured. The Journal of Consumer Marketing, 6, 1, 5-12.

De Chernatony, L. (1999). Brand management through narrowing the gap between brand identity and brand reputation. Journal of Marketing Management, 15, 157-179. 
de Chernatony, L. and Cottam, S. (2006). Internal brand factors driving successful financial services brands. European Journal of Marketing, 40, 5-6, 611-633.

Denscombe, M. (2003). The Good Research Guide: for small-scale social research projects, second edition. Open University Press, Berkshire.

Denzin, N. K. and Lincoln, Y. S. (2017). The SAGE Handbook of Qualitative Research, $5^{\text {th }}$ Edition. SAGE Publications Inc, London.

Doherty, S. and Nelson, R. (2010). Using projective techniques to tap into consumers' feelings, perceptions and attitudes...getting an honest opinion. International Journal of Consumer Studies, 34, 400-404.

Donoghue, S. (2000). Projective techniques in consumer research. Journal of Family Ecology and Consumer Sciences, 28, 1, 47-53.

Durvasula, S. Lysonski, S. and Madhavi, A. D. (2011). Beyond service attributes: do personal values matter. Journal of Services Marketing, 25, 1, 33-46.

Escribanoa, M. Gasparb, P. and Mesias, F.J. (2020). Creating market opportunities in rural areas through the development of a brand that conveys sustainable and environmental values. Journal of Rural Studies, 75 (2020) 206-2015.

Farook, M. R. M. (2013). An investigation of perceived brand identity and actual brand image of general practice (GP) in the UK. The Business and Management Review, 3, 4, 60.

Fisher, C. (2010). Research and Writing a Dissertation: an essential guide for business students, third edition. Pearson Education Limited, Essex.

Fetscherin, M. and Usunier, J. C. (2012). Corporate branding: an interdisciplinary literature review. European Journal of Marketing, 46, 5, 733-753.

Flick, U. (2006). An introduction to qualitative research, third edition. Sage Publications Limited, London.

Furey, S. Pringer, P. and Parsons, C. (2014). Journal of Marketing for Higher Education, 24, 1, 99-121.

Gabrielli, V. and Baghi, I. (2015). Brand architecture shift and corporate brand equity. Marketing Intelligence \& Planning, 34, 6, 777-794.

Gillham, B. (2000). The Research Interview. Continuum, London: England.

Gordon, W. (1999). Goodthinking: A Guide to Qualitative Research. Oxfordshire: Admap Publications.

Gordon, W. and Langmaid, R. (2008). Qualitative Market Research; A Practitioner's and Buyer's

Guide. Hants, England: Gower Publishing Company Ltd.

Gronhoj, A. and Gram, M. (2020). Researching family food decision making processes: highlights, hits and pitfalls when including young children's perspectives. Qualitative Market Research: An International Journal. DOI 10.1108/QMR-03-2019-0048.

Gutman, J. and Miaoulis, G. (2003). Communicating a quality position in service delivery: an application in higher education. Managing Service Quality, 13, 2, 105-111.

Harris, F. and de Chernatony, L. (2001). Corporate branding and corporate brand performance, European Marketing Journal, 35, 3-4, 441-456. 
Hatch, M. J. and Schultz, M. (2003). Bringing the corporation into corporate branding. European Journal of Marketing, 37, 1041-1064.

He, H. W. and Balmer, J. M. T. (2007). Identity studies: multiple perspectives and implications for corporate-level marketing. European Journal of Marketing, 41, 7-8, 765-785.

Hemsley-Brown, J. and Goonawardana, S. (2007). Brand harmonization in the international higher education market. Journal of Business Research, 60, 9, 942-948.

Hemsley-Brown, J. Melewar, T. C. Nguyen, B. Wilson, E.J. (2016). Exploring brand identity, meaning, image and reputation (BIMIR) in higher education: A special edition. Journal of Business Research, 69, 3019-3022.

Hemsley-Brown, J. and Oplatka, I. (2006). Universities in a competitive global marketplace: a systematic review of the literature on higher education marketing. International Journal of Public Sector Management, 19, 4, 316-338.

Hofstede, A. van Hoof, J. Walenberg, N. and de Jong, M. (2007). Projective techniques for brand image research: two personification-based methods explored. Qualitative Market Research: An International Journal, 10, 3, 300-309.

Janetius, S. Varma, P. and Shilpa, S. (2019). Projective tests in human resource management and hiring process: a challenge and a boon. The International Journal of Indian Psychology, 7 (4), pp. 258265.

Jevons, C. (2006). Universities: a prime example of branding going wrong. Journal of Product \& Brand Management, 15, 7, 466-467.

Jimenez-Barreto, J. Rubio, N. Campo, S .Molinillo, S. (2020). Linking the online destination brand experience and brand credibility with tourists' behavioral intentions toward a destination. Tourism Management, doi.org/10.1016/j.tourman.2020.104101.

Kapferer, J. N. (2012). The New Strategic Brand Management: Advanced Insights \& Strategic Thinking. Kogan Page Limited, London.

Kay, D. (2001). Going beyond words: how researchers are using projective techniques to better understand people's views of brands. Marketing Magazine, 106, 22.

Kotler, P. Keller, K. L. Brady, M. Goodman, M. and Hansen, T. (2009). Marketing Management. Essex: Pearson Education Limited.

Lages, F. L. and Fernandes, J. C. (2005). The SERPVAL scale: a multi-item instrument for measuring service personal values. Journal of Business Research, 58, 1562-1572.

Lewis, J. and McNaughton, N. C. (2014). Design issues. In : Qualitative Research Practice: a guide for social science students \& researchers, second edition. Ritchie J, Lewis J, McNaughton Nicholls C, Ormston R (eds), Sage Publications, London.

Melewar, T. C. and Karaosmanoglu, E. (2006). Seven dimensions of corporate identity: a categorisation from the practitioners' perspectives. European Journal of Marketing, 40, 7/8, 846869.

Miles, M. B. and Huberman, A. M. (1994). Qualitative Data Analysis, second edition. Sage Publications, California. 
Morrison, M.A. Haley, E. Bartel, S. K. and Taylor, R. E. (2002). Using Qualitative Research in Advertising, Strategies, Techniques and Applications, Sage, Thousand Oaks, CA.

Murdaugh, C. Russell, R. B. Sowell, R. (2000). Using focus groups to develop a culturally sensitive videotape intervention for HIV-positive women. Journal of Advanced Nursing, 32, 6, 1507-1513.

Nandan, S. (2005). An exploration of the brand identity-brand image linkage: a communications perspective. Brand Management, 12, 4, 264-278.

Oswick, C. and Montgomery, J. (1999). Images of an organisation: the use of metaphor in a multinational company. Journal of Organisational Change Management, 12, 6, 501-23.

Perez, A. (2015). Corporate reputation and CSR reporting to stakeholders. Gaps in the literature and future lines of research. Corporate Communications: An International Journal, 20, 1, 11-29.

Pettigrew, S. and Charters, S. (2008). Tasting as a projective technique. Qualitative Market Research, 11, 3, 331-43.

Pich, C. Armannsdottir, G. and Spry, L. (2018). Investigating political brand reputation with qualitative projective techniques from the perspective of young adults. International Journal of Market Research, 60, 2, 198-213.

Pich, C. and Dean, D. (2015). Qualitative projective techniques in political brand image research from the perspective of young adults. Qualitatitive Market Research, 18, 1, 115-144.

Pinar, M. Trapp, P, Girard, T. and Boyt, T. E. (2011). Utilizing the brand ecosystem framework in designing branding strategies for higher education. International Journal of Educational Management, 25, 7, 724-739.

Porr, C. Mayan, M. Graffigna, G. Wall, S. and Vieira, E.R. (2011). The evocative power of projective techniques for the elicitation of meaning. International Institute for Qualitative Methods, 10, 1, 3041.

Prayag, G. (2007). Exploring the Relationship between Destination Image \& Brand Personality of a Tourist Destination - An Application of Projective Techniques. Journal of Travel and Tourism Research, 7, 2, 111-130.

Rindell, A. and Strandvik, T. (2010). Corporate brand evolution: corporate branding images evolving in consumers' everyday life. European Business Reviews, 22, 3, 276-286.

Rokeach, M. (1973). The Nature of Human Values, Free Press, New York, US.

Roper, S. and Fill, C. (2012). Corporate Reputation: brand and communication. Pearson Education, Essex.

Saunders, M. Lewis, P. and Thornhill, A. (2009). Research Methods for Business Students, fifth edition. Pearson Education Limited, Essex, England.

Schlesinger, W. Cervera, A. Pérez-Cabañero, A. (2016). Sticking with your university: the importance of satisfaction, trust, image, and shared values. Studies in Higher Education, DOI:

10.1080/03075079.2015.1136613

Silverman, D. (2013). Doing Qualitative Research, fourth edition. Sage Publications Limited, London. 
Soley, L. and Smith, A. L. (2008). Projective Techniques for Social Science and Business Research. Southshore Press, Milwaukee, Wisconsin, USA.

Spencer, L. Ritchie, J. Ormston, R. O'Connor, W. and Barnard, M. (2014). In: Qualitative Research Practice: a guide for social science students \& researchers, second edition. Ritchie, J. Lewis, J. McNaughton, N. C. Ormston, R. (eds), Sage Publications, London.

Steiner, L. Sundström, A. C. and Sammalisto, K. (2012). An analytical model for university identity and reputation strategy work. Higher Education, 65, 401-415.

Steinmann, R. B. (2009). Projective techniques in consumer research. International Bulletin of Business Administration, 37-45.

Stephenson, A. L. Heckert A. and Yerger, D. B. (2015). College choice and the university brand: exploring the consumer decision framework. Higher Education, 71, 4, 489-503.

Tantiseneepong, N. Gorton, M. and White, J. (2012). Evaluating responses to celebrity endorsements using projective techniques. Qualitative Market Research: An International Journal, $15,1,57-69$.

Timmor, Y. and Rymon, T. (2005). To do or not to do: the dilemma of technology-based service improvement, Journal of Services Marketing, 21, 2, 99-111.

Uggla, H. (2006). The corporate brand association base. European Journal of Marketing, 40, 7-8, 785-802.

Van Riel, C. B. M. (1992). Principles of Corporate Communication, Prentice-Hall, Harlow.

Vince, R. and Broussine, M. (1996). Paradox, Defence and Attachment: Accessing and Working with Emotions and Relations Underlying Organisational Change, Organisation Studies, 17, 1, 1-21.

Waeraas, A. (2008). Can public sector organisations be coherent corporate brands? Marketing Theory, 8, 205-221.

Waerass, A. and Solbakk, N. (2009). Defining the essence of a university: Lessons from higher education branding. Higher Education, 57, 4, 449-462.

Whisman, R. (2009). Internal branding: a university's most valuable intangible asset. Journal of Product \& Brand Management, 18, 5, 367-370.

Will, V. Eadie, D. and MacAskill, S. (1996). Projective and enabling techniques explored. Marketing Intelligence \& Planning, 14, 6, 38-43.

Yin, R. K. (2009). Case Study Research: Design and Methods, fourth edition. Sage Publications Inc, California, US. 